http:/www.journals.zu.edu.eg/journalDisplay.aspx?Journalld=1\&queryType=Master

\title{
FACTORS AFFECTING THE CHEMICAL BEHAVIOUR OF SOME AMMONIACAL NITROGEN FERTILIZERS IN TWO DIFFERENT SOILS
}

\author{
Hala S.M. Ali ${ }^{*}$, I.R. Mohamed, S.M. Dahdouh and A.S. Metwally \\ Soil Sci., Dept., Fac. Agric., Zagazig Univ., Egypt
}

Received: 03/10/2017 ; Accepted: 24/10/2017

\begin{abstract}
Chemical behaviour of certain ammoniacal nitrogen fertilizers in a clay soil and a sand soil was studied. In a laboratory study, water soluble ammonium values in the sandy soil was greater than those in the clay one. Exchangeable ammonium values in the clay soil were more than those in the sandy soil. The greatest percent of nitrified nitrogen was found in the clay and sandy soils treated with $\mathrm{NH}_{4} \mathrm{NO}_{3}$, whereas the clay and sandy soils showed the lowest one when $\mathrm{NH}_{4} \mathrm{OH}$ was used. The loss volatilization of nitrogen as $\mathrm{NH}_{3}$ or the leaching loss from soil columns was greater from the sandy soil than from the clay soil. The $\mathrm{NH}_{3}$ volatilization was greater from $\mathrm{NH}_{4} \mathrm{OH}$ compared with $\left(\mathrm{NH}_{4}\right)_{2} \mathrm{SO}_{4}, \mathrm{NH}_{4} \mathrm{NO}_{3}$ and $\mathrm{NH}_{4} \mathrm{Cl}$. Loss through leaching was greater from $\mathrm{NH}_{4} \mathrm{NO}_{3}$ compared with $\left(\mathrm{NH}_{4}\right)_{2} \mathrm{SO}_{4}, \mathrm{NH}_{4} \mathrm{OH}$ and $\mathrm{NH}_{4} \mathrm{Cl}$.
\end{abstract}

Key words: Ammoniacal nitrogen fertilizers, clay and sandy soils, N-leaching and ammonia volatilization.

\section{INTRODUCTION}

Under Egyptian soil conditions, there are some factors affecting the behviour of $\mathrm{N}$ fertilizers such as $\mathrm{pH}$ value, calcium carbonateclay and organic matter contents. These factors affect transformation of ammoniacal fertilizers. Studying the behaviour of ammoniacal nitrogen fertilizers under Egyptian soil conditions certainly will help effecient utilization of such fertilizers.

To accomplish this work, some factors such as soil texture, $\mathrm{CaCO}_{3}$ content and loss of nitrogen by volatilization and leaching, which may affect available nitrogen in soil are studied using laboratory experiments.

\section{MATERIALS AND METHODS}

\section{Materials}

\section{Soil sample}

Two different soil samples were collected from the surface $0-30 \mathrm{~cm}$ for this study. The soils were as follows:
1- A clay soil from an arable field in AbuHammad District, Sharkia Governorate, Egypt.

2- A Sandy soil from the Farm of the Faculty of Agriculture, at El-Khattara, Zagazig Univ., Sharkia Governorate, Egypt.

Soil samples were air dried, crushed, sieved through $2 \mathrm{~mm}$ plastic screen, throughly mixed and stored in plastic bags for analysis and experimental work. Table 1 shows some physical and chemical characteristics of the studied soils.

Soil analyses were done according to methods described by Black et al. (1965).

\section{Mineral fertilizers}

Nitrogenous fertilizers used as nitrogen sources are ammonium sulphate (AS), ammonium nitrate (AN), ammonium hydroxid $(\mathrm{AH})$, and ammonium chloride (AC).

\section{Experimental methods}

A laboratory study was carried out to assess the behaviour of some ammoniacal nitrogen fertilizers added to the clay and sandy soils.

\footnotetext{
* Corresponding author: Tel. : +201096132648

E-mail address:
} 
Water soluble and exchangeable ammonium$\mathbf{N}$ in the soils

For determination of water soluble and exchangeable $\mathrm{NH}_{4}^{+}-\mathrm{N}$ were extracted (Balba et al., 1969) and determined according to the method described by Hesse (1971).

\section{Nitrification of ammonium}

Portions of $100 \mathrm{~g}$ of air dried soil in plastic pots $(8 \mathrm{~cm}$ diameter and $6 \mathrm{~cm}$ high) were used. Nitrogen was added as $\left(\mathrm{NH}_{4}\right)_{2} \mathrm{SO}_{4}, \mathrm{NH}_{4} \mathrm{NO}_{3}$, $\mathrm{NH}_{4} \mathrm{OH}$ and $\mathrm{NH}_{4} \mathrm{Cl}$ at the rate of $56 \mathrm{mg} \mathrm{N} / 100 \mathrm{~g}$ soil, ( $\equiv 4$ cmolc kg ${ }^{-1}$ soil).

The pots were placed at room temperature (about $25^{\circ} \mathrm{C}$ ) for one month. Soil moisture was maintained at the field capacity by adding the required amount of water every two days. Nitrate nitrogen in the soil was determined at the end of the incubation period using the methods described by Hesse (1971).

Ammonia loss by volatilization from different nitrogen fertilizers added to the investigated soils

Ammonia loss by volatilization was determined using modified micro-diffusion unit according to method described by Hesse (1971). Portions of $100 \mathrm{~g}$ air dried soil were placed in the outer plastic container and $4 \%$ boric acid with bromo creasol green-methyl red indecator was placed in the inner container. The vessel was covered with a plastic lid sealed with vaseline. Nitrogen was added as $\left(\mathrm{NH}_{4}\right)_{2} \mathrm{SO}_{4}, \mathrm{NH}_{4} \mathrm{NO}_{3}$, $\mathrm{NH}_{4} \mathrm{OH}$ and $\mathrm{NH}_{4} \mathrm{Cl}$ at the rate of $1 \mathrm{~g} \mathrm{Nkg}^{-1}$ soil. Soil moisture was maintained at field capacity through the experimental period. Treatments were replicated two times. The plastic vessels were covered and incubated at room temperature (about $25^{\circ} \mathrm{C}$ ) for one month. Evolved ammonia was trapped in boric acid and titrated with 0.01 M hydrochloric acid.

Nitrogen loss by leaching from different nitrogen fertilizers added to soils under study

Portions of $400 \mathrm{~g}$ soil were packed in columns using plastic cylenders. The columns were $30 \mathrm{~cm}$ long and $4.5 \mathrm{~cm}$ in diameter. The bottoms of cylenders were perforated to facilitate drainage. Nitrogen fertilizers such as $\left(\mathrm{NH}_{4}\right)_{2} \mathrm{SO}_{4}, \mathrm{NH}_{4} \mathrm{NO}_{3}, \mathrm{NH}_{4} \mathrm{OH}$ and $\mathrm{NH}_{4} \mathrm{Cl}$ were mixed through within the upper $5 \mathrm{~cm}$ of the soil columns at the rate of $200 \mathrm{mg} \mathrm{N}$ per column $(0.5$ $\mathrm{g} / \mathrm{kg}$ soil). The soil moisture was kept at field capacity. Soluble nitrogen forms of ammonium and nitrate were determined in leachates.

\section{RESULTS AND DISCUSSION}

\section{Water Soluble and Exchangable of Ammonium Added to Soils under Study}

Results in Table 2 show values of soluble and exchangeable ammonium ions. In studied soils, $\left(\mathrm{NH}_{4}\right)_{2} \mathrm{SO}_{4}, \mathrm{NH}_{4} \mathrm{NO}_{3}$ and $\mathrm{NH}_{4} \mathrm{Cl}$, showed higher soluble and exchangeable ammonium ions as compared with the $\mathrm{NH}_{4} \mathrm{OH}$ fertilizer. The obtained results might be explained on the basis of acidity of those salts compared with the alkalinity of $\mathrm{NH}_{4} \mathrm{OH}$, (Osman 1975) and Mohamed et al., (1986).

Comparing the different soils, values of water soluble $\mathrm{NH}_{4}^{+}$in the sandy soil was greater than those in a clay soil. Values of exchangeable ammonium were higher in the clay soil than those in the sandy one reflecting the higher cation exchange capacity (CEC) of the clay soil.

\section{Nitrification of Ammoniacal Nitrogen in Soil}

The values representing the content of soluble $\mathrm{NO}^{-}-\mathrm{N}$ as well as percents of nitrified nitrogen are shown in Table 3. Results, generally, showed that the absolute amounts of soluble $\mathrm{NO}_{3}^{-}$and percents of nitrified nitrogen in all treatments receiving fertilizers in the two studied soils increased as compared with those of the control. This caused the enhanced of microbial activity brought about by applied ammonium salts through the incubation period, (Ardakani et al., 1974; Osman, 1975; Mohamed et al., 1986; Dahdouh et al., 2004 ; Merwad, 2009).

The values of $\mathrm{NO}_{3}^{-}-\mathrm{N}$ and percents $\mathrm{N}$ nitrified in the two different soils treated with $\mathrm{NH}_{4} \mathrm{NO}_{3}$ were relatively higher than those of the other three fertilizers. $\mathrm{NH}_{4} \mathrm{NO}_{3}$ in these soils was more favourable for the maximum rate of nitrification (Tisdale and Nelson, 1970; Osman, 1975; Mohamed et al., 1986).

The $\mathrm{NO}_{3}^{-}-\mathrm{N}$ given by $\mathrm{NH}_{4} \mathrm{OH}$ was lower value than given by the other three fertilizers due to biological and chemical transformation of ammonia. 
Table 1. Some physical and chemical properties of the studied soils

\begin{tabular}{|c|c|c|c|c|c|}
\hline \multirow{2}{*}{$\begin{array}{l}\text { Soil property } \\
\text { Soil particles size } \\
\text { distribution }\end{array}$} & \multicolumn{2}{|c|}{ Soil location } & \multirow{2}{*}{$\begin{array}{c}\text { Soil property } \\
\begin{array}{c}\text { Soluble cations } \\
\text { and anions, cmolcl }\end{array}\end{array}$} & \multicolumn{2}{|c|}{ Soil location } \\
\hline & Abu-Hammad & El-Khattara & & Abu Ham & El-Khattara \\
\hline$\overline{\text { Sand }(\%)}$ & 30.63 & 91.20 & $\mathrm{Ca}^{++}$ & 7.9 & 5.36 \\
\hline Silt (\%) & 20.30 & 2.59 & $\mathrm{Mg}^{++}$ & 6.1 & 4.00 \\
\hline Clay $(\%)$ & 49.07 & 6.21 & $\mathrm{Na}^{+}$ & 6.85 & 3.72 \\
\hline Textural class & Clay & Sand & $\mathrm{K}^{+}$ & 0.25 & 0.11 \\
\hline Field capacity (\%) & 30 & 12 & $\mathrm{CO}_{3}{ }^{=}$ & - & - \\
\hline $\mathrm{CaCO}_{3},\left(\mathrm{gkg}^{-1}\right)$ & 10 & 28.5 & $\mathrm{HCO}_{3}^{-}$ & 3.8 & 2.8 \\
\hline Organic matter $\left(\mathrm{gkg}^{-1}\right)$ & 16.2 & 5 & $\mathrm{Cl}^{-}$ & 10.9 & 4.39 \\
\hline CEC cmolc kg ${ }^{-1}$ soil & 42.0 & 9.0 & $\mathrm{SO}_{4}^{=}$ & 6.4 & 6.00 \\
\hline pH* & 8.2 & 8.0 & & & \\
\hline $\operatorname{EC}\left(\mathrm{dSm}^{-1}\right)^{* *}$ & 2.1 & 1.26 & & & \\
\hline
\end{tabular}

* Soil-water suspention 1:2.5

** Soil paste extract

Table 2. Water soluble and exchangeable ammonium (cmolc $\mathrm{kg}^{-1}$ soil) as influenced by different $\mathrm{N}$ sources added to the two tested soils.

\begin{tabular}{|c|c|c|}
\hline Treatment & Solube $\mathrm{NH}_{4}^{+}$ & ${\operatorname{Exch} . \mathrm{NH}_{4}^{+}}_{4}$ \\
\hline & \multicolumn{2}{|c|}{ Clay soil } \\
\hline Untreated & 0.06 & 1.09 \\
\hline$\left(\mathrm{NH}_{4}\right)_{2} \mathrm{SO}_{4}$ & 1.00 & 3.7 \\
\hline $\mathrm{NH}_{4} \mathrm{NO}_{3}$ & 0.97 & 3.60 \\
\hline $\mathrm{NH}_{4} \mathrm{OH}$ & 0.89 & 3.10 \\
\hline \multirow[t]{2}{*}{$\mathrm{NH}_{4} \mathrm{Cl}$} & 1.30 & 3.50 \\
\hline & \multicolumn{2}{|c|}{ Sandy soil } \\
\hline Untreated & 0.02 & 0.36 \\
\hline$\left(\mathrm{NH}_{4}\right)_{2} \mathrm{SO}_{4}$ & 2.52 & 1.65 \\
\hline $\mathrm{NH}_{4} \mathrm{NO}_{3}$ & 2.86 & 1.36 \\
\hline $\mathrm{NH}_{4} \mathrm{OH}$ & 2.40 & 1.40 \\
\hline $\mathrm{NH}_{4} \mathrm{Cl}$ & 2.60 & 1.70 \\
\hline
\end{tabular}


Ali, et al.

Table 3. Nitrification of added nitrogen fertilizers after one month in two different soils

\begin{tabular}{|c|c|c|}
\hline Treatment & $\mathrm{NO}_{3}^{-}$formed cmolc $\mathrm{N} / \mathrm{kg}$ soil & Percent $\mathrm{N}$ nitrified \\
\hline & \multicolumn{2}{|c|}{ Clay soil } \\
\hline Untreated & 0.90 & - \\
\hline$\left(\mathrm{NH}_{4}\right)_{2} \mathrm{SO}_{4}$ & 3.10 & 55.0 \\
\hline $\mathrm{NH}_{4} \mathrm{NO}_{3}$ & 3.75 & 71.3 \\
\hline $\mathrm{NH}_{4} \mathrm{OH}$ & 2.50 & 40.0 \\
\hline \multirow[t]{2}{*}{$\mathrm{NH}_{4} \mathrm{Cl}$} & 3.08 & 54.5 \\
\hline & \multicolumn{2}{|c|}{ Sandy soil } \\
\hline Untreated & 0.30 & - \\
\hline$\left(\mathrm{NH}_{4}\right)_{2} \mathrm{SO}_{4}$ & 1.80 & 37.5 \\
\hline $\mathrm{NH}_{4} \mathrm{NO}_{3}$ & 2.10 & 45.0 \\
\hline $\mathrm{NH}_{4} \mathrm{OH}$ & 1.30 & 25.0 \\
\hline $\mathrm{NH}_{4} \mathrm{Cl}$ & 1.70 & 35.0 \\
\hline
\end{tabular}

The lowest $\mathrm{NO}_{3}^{-}-\mathrm{N}$ values and nitrified $\mathrm{N}$ percents were found in the sandy soil treated with $\mathrm{NH}_{4} \mathrm{OH}$, possibly due to its low cation exchang capacity and presence of $\mathrm{CaCO}_{3}$. These results are in agreament with those obtained by Swart et al. (1971), Fenn and Kissel (1974), Mohamed et al. (1986) and Dahdouh et al. (2004).

Regarding the nitrified $\mathrm{N}$ percent in soils, results indicated that, this percent ratio was dependent upon the nature of ammonium source, the cation exchang capacity, and the calcium carbonate content. The nitrified $\mathrm{N}$ percent was higher in the clay soil than the sandy soil, indicating a reaction of the added ammonium fertilizers with the $\mathrm{CaCO}_{3}$ in the sandy soil causing formation of $\left(\mathrm{NH}_{4}\right)_{2} \mathrm{CO}_{3}$, which dissotiates forming $\mathrm{NH}_{3}$, which is lost by volatilization and losses of ammonia (Larsen and Gunary, 1962).

\section{Compartive Loss by Volatilization of Ammonia from Nitrogen Fertilizers Added to the Investigated Soils}

The susceptibility of ammoniacal fertilizers added to the soil to loss through volatilization as $\mathrm{NH}_{3}$ was examined, Table 4 shows that loss of nitrogen added as fertilizers by volatilization as $\mathrm{NH}_{3}$ was greater from the sandy soil than from the clay one. This is most certainly due to presence of $\mathrm{CaCO}_{3}$ and also to the low cation exchang capacity of the sandy soil. Loss of nitrogen through volatilization was greater from $\mathrm{NH}_{4} \mathrm{OH}$ than that from the other ammoniacal nitrogen fertilizers since $\mathrm{NH}_{4} \mathrm{OH}$ is easily dissociated evolving $\mathrm{NH}_{3}$ gas.

Ammonia volatilization is depends upon the nature of ammonium source, the cation exchange capacity, the soil content of calcium carbonate, the $\mathrm{pH}$ of the soil, the temperature, the depth of the fertilizer placement and the soil moisture content (Fuller, 1963, Mohamed et al., 1986 ; Dahdouh et al., 2004).

\section{Loss of Nitrogen by Leaching from Applied Ammoniacal Fertilizers}

Table 5, shows the loss of nitrogen in the leachates. The quantity of leached nitrogen from the sandy soil was greater than that from clay one. This is a demonstration of the soil texture, cation exchange capacity and fixation of ammonium in soils as well as the difference in nitrification rate (Fuller, 1963) and (Mohamed 1976). This finding is in agreement with that 
Table 4. Loss ammonia by volatilization form nitrogen fertilizers added to the soils

\begin{tabular}{lcc}
\hline Treatment & Clay soil & Sandy soil \\
\hline & \multicolumn{2}{c}{ Percent N lost of added } \\
Untreated & 1.2 & 0.5 \\
$\left.\mathbf{N H}_{4}\right)_{2} \mathbf{S O}_{4}$ & 15.5 & 24.5 \\
$\mathbf{N H}_{4} \mathbf{N O}_{3}$ & 5.3 & 10.7 \\
$\mathbf{N H}_{\mathbf{4}} \mathbf{O H}$ & 20.9 & 41.8 \\
$\mathbf{N H}_{4} \mathbf{C l}$ & 12.5 & 19.9 \\
\hline
\end{tabular}

Table 5. The leaching losses of available-N from soils treated with various nitrogen fertilizers

\begin{tabular}{lcccc}
\hline Treatment & \multicolumn{2}{c}{ Clay soil } & \multicolumn{2}{c}{ Sandy soil } \\
\cline { 2 - 5 } & mg N/ soil column & Added N (\%) & mg N/ soil column & Added N (\%) \\
\hline Non-fertilized & 2.00 & - & 0.0 & - \\
$\left.\mathbf{N H}_{4}\right)_{2} \mathbf{S O}_{4}$ & 39.50 & 18.8 & 60.5 & 30.3 \\
$\mathbf{N H}_{4} \mathbf{N O}_{3}$ & 55.80 & 27.9 & 93.5 & 46.8 \\
$\mathbf{N H}_{\mathbf{4}} \mathbf{O H}$ & 23.60 & 10.8 & 40.8 & 20.4 \\
$\mathbf{N H}_{4} \mathbf{C l}$ & 30.80 & 15.4 & 57.8 & 28.8 \\
\hline
\end{tabular}

obtained by Mohamed (1976), Mohamed et al. (1986) Dahdouh et al. (2004) and Merwad (2009).

Comparing the different forms of nitrogen applied, the amount of available-N lost by leaching was in the following descending order: $\mathrm{NH}_{4} \mathrm{NO}_{3}>\left(\mathrm{Nh}_{4}\right) \mathrm{SO}_{4}>\mathrm{NH}_{4} \mathrm{cl}>\mathrm{NH}_{4} \mathrm{OH}$. This reflects the different nature of nitrogen sources. These findings are in agreement with those obtained by Fuller (1963), Mohamed et al., (1976), Dahadouh et al. (2004) and Merwad (2009).

\section{REFERENCES}

Ardakani, M.S., J.T. Rehbock and T. Mclaren (1974). Oxidation of ammonium to nitrate in soil column Soil Sci. Soc. Ame. Proc., 38: 96-101.

Balba, A.M., M.G. Nasseem and S. El-Massry (1969). A preliminary study of soil fertility of the Nasser project Along the N.W. coast of ARE. Egypt. J. Soil Sci., Ix (1): 26-34.

Black, C.A., D.D. Evans, J.L. White, L.E. Ensminger and F.E. Chark (1965). Methods of Soil Analysis, part 2 Ame. Soc. Agron., INC publisher, Madison, Wisconsin, USA.

Dahdouh, S.M., F.A.A. Osman and M.E. ElAzab (2004). Nitrogen loss from sandy soils treated with manure and $\mathrm{N}$ fertilizers with and without nitrification inhibitor, Egypt J. Soil, Sci., 44 (4): 531-546.

Fenn, L.B. and D.E. Kissel (1974). Ammonia volatilization from surface application of ammonia compounds on calcareous soils. Soil Sci. Soc. Ame. Proc., 38: 606-610.

Fuller, W.H. (1963). Reaction of nitrogenous fertilizers in calcareous soils. Ame. Chem. Soc., 11: 188-193.

Hesse, P.R. (1971). A Text Book of Soil Chemical Analysis, John Murray, London, UK. 
Larsen, S. and D. Gunary (1962). Ammonia loss from ammoniacal fertilizers applied to calcareous soils, J. Sc. Food Agric., 13 : 566572.

Merwad, A.M.A. (2009). Effect of some amendments on the behaviour of some nutrients in different soils. M. Sc. Thesis, Fac. Agric. Zagazig Univ., Egypt.

Mohamed, I.R. (1976). A comparative study between organic and inorganic nitrogen fertilizers in calcareous soil. M. Sc. Thesis, Fac. of Agric. Ain-Shams Univ., Egypt.

Mohamed, I.R., E.E. Fouda and K.F. Mousa (1986). Factors affecting the utilization of nitrogen fertilizers by plants in soils. Zagazig Agric. Res., 13 (2): 514-536.

Osman, A.O. (1975). Studies on chemical behaviour of certain nitrogenous forms in some Egyptian soils M.Sc. Thesis, Fac. Agric., Ain-Shams Univ.

Swart, C.L., L.S. Murphy and C.W. Swallow (1971). Retention patterns and effectiveness of anhydrous ammonia applied with under culting blade. Agron, J., 63: 881-886.

Tisdale, S.L. and W.L. Nelson (1970). Soil Fertility and Fertilizers (second edition) the Macmillan Co. NY USA.

\section{العوامل المؤثرة على السلوك الكيميائى لبعض الأسمدة النيتروجينية الأمونيوميه فى أرضين مختلفتين

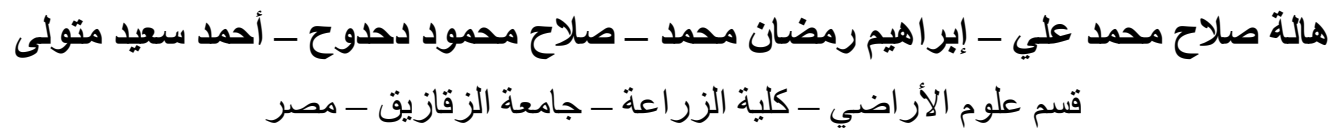

يهذف هذا البحث إلى دراسة بعض العوامل المؤثرة على السلوك الكيميائي لبعض الأسمدة النيتروجينية في الصورة

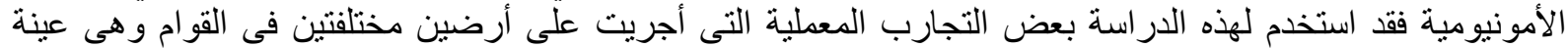

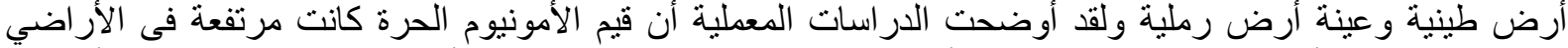

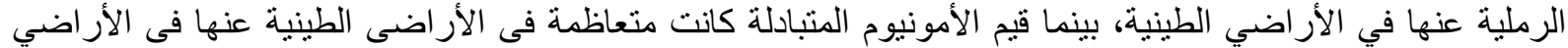

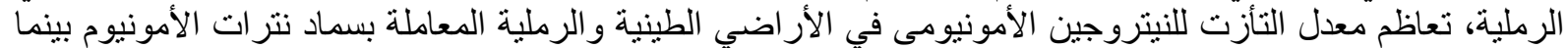

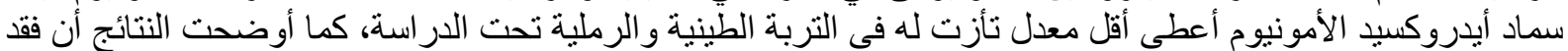

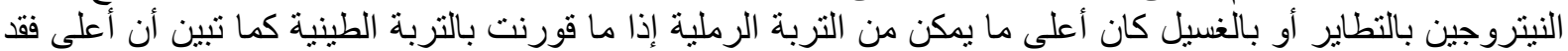

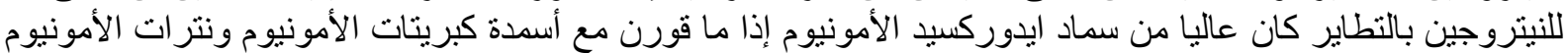

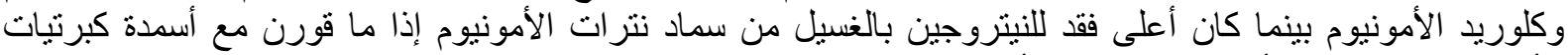

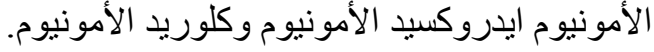

أستاذ الأر اضي المتفرغ - كلية الزر اعة بمشتهر - جامعة بنها. أستاذ الأر اضي المتفرغ غ - كلية الزر اعة - جامعة الزقازيق. 